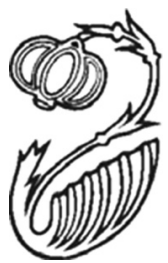

\title{
Classical Greek Ethnography and the Slave Trade
}

\begin{abstract}
This paper draws upon analogy with better documented slave societies (the medieval Islamic world, and the 18th-century Caribbean) to argue, first, that the institution of slavery was a major factor in fostering a discourse on the differences among foreign peoples; and secondly, that Greek ethnographic writing was informed by the experience of slavery, containing implicit justifications of slavery as an institution. It then considers the implications of these conclusions for our understanding of Greek representations of the barbarian world and for Greek contact with non-Greeks.
\end{abstract}

Since Aristotle's Politics, the Greek association between slavery and foreign peoples has been well established. Given that slavery was an "essential institution" in Greek society, and that the slave population was made up of non-Greeks, "it does not take much thinking," as Kostas Vlassopoulos has put it, "to understand why the Greeks might have despised barbarians and consider them slavish and inferior."1 "When Athenians thought about slaves," according to Vincent Rosivach, "they habitually thought about barbaroi, and when they thought about barbaroi they habitually thought about slaves." 2 This paper will develop the insights of previous

Versions of this paper have been delivered at the History Department of Lancaster University, a joint St Andrews and William and Mary College symposium, and a Cambridge teachers' conference organized by Ingo Gildenhard and Qasim Alli. I am grateful to all those who offered suggestions and comments, and especially, for guidance on Caribbean evidence, to Catherine Hall; on Arabic material, to Marek Jankowiak, Adam Simmons, Lisa Nielsen, and Pernilla Myrne (not least for sharing an important forthcoming article); and, for discussions of classical ethnography and slavery, to Antti Lampinen, Joe Skinner, Kelly Wrenhaven, Paul Cartledge, and Myles Lavan. My thanks also to Steven Johnstone and to the anonymous readers for Classical Antiquity for invaluable suggestions.

1. Vlassopoulos 2013: 5; cf. E. Hall 1989a: 164-65, 193-94, 196-97, J. Hall 2002: 186, Cartledge 1993a: 41.

2. Rosivach 1999: 129; cf. p. 154.

Classical Antiquity, Vol. 38, Issue 1, pp. 36-57. ISSN: 0278-6656(p); 1067-8344(e)

Copyright (C) 2019 by The Regents of the University of California. All rights reserved. Please direct all requests for permission to photocopy or reproduce article content through the University of California Press's Rights and Permissions website at http://www.ucpressjournals.com/reprintinfo.asp. DOI: https://doi.org/10.1525/ca.2019.38.1.36 
scholarship on both slavery and the representations of foreign people in suggesting, first, that the institution of slavery was a major factor in fostering a discourse on the differences among foreign peoples (not merely the idea of the barbarian as an indifferentiated group ${ }^{3}$ ); and secondly, more specifically, that Greek ethnographic writing was informed by the experience of slavery, containing implicit justifications of slavery as an institution.

The argument will depend on analogy with better documented slave societies. It is also predicated on some basic facts about Greek slavery: first, that the slave population in the Greek world was a significant one; secondly, that slaves werepredominantly, or to a very significant degree - perceived to be ${ }^{4}$ of foreign origin.

\section{A DISCOURSE ON SLAVE ORIGINS?}

It is arguable that wherever there is a market in human beings of diverse origins some discourse on the differences between groups will emerge. Contemporary discussion groups on identifying the best au-pairs for your family - though they may be peppered with embarrassed statements that individual character matters more than nationality - still perpetuate and act upon a set of powerful, collectively developed stereotypes: ${ }^{5}$

"We avoided Brazilian (reputation as party girls), Russians/Ukranians (looking to nab a husband), and Thai (alleged to be poor drivers) APs."

"S African = good English speakers, Western diets/culture

Brazillian $[$ sic $]=$ friendly and family orientated

German $=$ disciplinarians, good drivers

Thai $=$ good with babies, poor drivers"

3. Contrast the emphasis of Rosivach 1999: 142 on barbarians as a "single, comprehensive group" rather than "a diverse collection of peoples each with different national characteristics"; for the concept of the 'barbarian' as like a concertina, see Harrison forthcoming. See also the observations of Wrenhaven 2012: 35.

4. The distinction is important: after how many generations was a slave of foreign origin

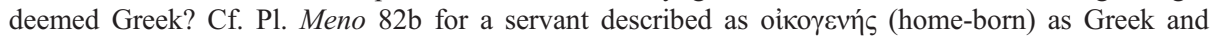
Greek-speaking. As observed by D. M. Lewis 2018: 279 n.34, such "designations . . obscure any trace of the ethnicity of the slave's parents." For the foreign background of slaves, see e.g., Rosivach 1999: 129-36, Garlan 1987: 12 ("No modern historian would dispute the fact that the great majority of slaves were not of Greek origin"), Vlassopoulos 2010, Wrenhaven 2012: 34-6. See further Tordoff 2013: 6-7, suggesting on the basis of extrapolation from the evidence from Laurion (Lauffer 1979: 123-28) that 90 percent of slaves employed in the silver mines were of foreign origin.

5. Discussion thread on "Choosing an Au Pair: how much does the home country matter?" (Harquail 2010). Embarrassed qualifications: even if "the stereotypes we experienced don't apply to all girls from these countries, we are not ready to risk it again." (PacificNW_mom April 29, 2010 $12: 41 \mathrm{pm})$. "Do I care if this sounds racist? A bit, which is why I didn't use my real name attached to this comment." (Marin County Twin Mom April 30, 2010 4:04pm).

6. West Coast Mom April 29, 2010 1:27pm; TX Mom April 29, 2010 3:16pm. 
More closely comparable to the Greek context, however, are the discourses on slave origins that survive from medieval and early modern slave societies. The 11th-century Christian doctor Ibn-Butlān, for example, in addition to his well-known treatise on the "maintenance of health" (the Taqwim al-Sihhah, or Tacuinum Sanitatis), authored an Epistle on the purchase of slaves and examining bondmen (Risāla fì shirā' al-raqīq wa-taqlīb al- 'abìd), an account of the qualities of slaves from different regions, balancing the strengths and weaknesses of a particular people and diagnosing their suitability for particular forms of labor. ${ }^{7}$ The women of Zaghāwa, according to Ibn-Butlān, "are of vicious character and full of grumbles," "useless for pleasure" as their men are "useless for service"; the Bujja are both innately brave and thievish, consequently unsuitable for use as treasurers or custodians; and the Armenians (who "would be thought beautiful were it not for their peculiarly ugly feet"), "are well-built, energetic and strong" but lacking in chastity, and "coarse in nature and speech," so fit for "hard work and service." According to Ibn-Butlān,

[Indian women have] good stature, brown color, and a plentiful share of beauty, with pallor, a clear skin, fragrant breath, softness, and grace, but old age comes quickly upon them. They are faithful and affectionate, very reliable, deep, sharp-tongued, and of fine character. They cannot support humiliation but endure pain without complaint until they are killed. They can master great things when compelled or provoked. Their women are good for childbirth, their men for the protection of persons and property and for delicate handicrafts. They catch cold easily. ${ }^{9}$

A similar pattern of ideas, in particular the matching of (ethnic) background with types of labor, is also common to the Atlantic slave trade. So, for example, an Italian Jesuit's advice to Brazilian sugar-planters on the treatment of their slaves similarly expresses firm views:

the Ardas and Minas slaves are robust, whereas those from Cape Verde and São Tomé are weaker. Slaves from Angola who grow up in Luanda are more capable of learning mechanical trades. . . Among the Congos,

7. For lengthy extracts from Ibn-Butlān's Shirā' al-Raqīq, see B. Lewis 1974: 243-51; for Arabic text, Harun 1954: 383-420; translations in German (abridged) and Italian exist by Müller 1980: 46-47, and Ghersetti 2001. For the wider tradition of Arabic slave manuals, see esp. Myrne forthcoming. For Arabic slavery more broadly, see Goitein 1993: 130-47, 431-37, B. Lewis 1992, Brunschvig 2012, Perry 2014; B. Lewis 1992: 43 -53 for a wider survey of stereotyping of foreigners. Cortese and Calderine's 2006: 204-205 matter-of-fact summary of representations of female slaves is uncannily similar to modern stereotyping: "Berber women were deemed good for housework, sex and child-bearing; black women were considered docile, robust and excellent wetnurses; Byzantine slavegirls could be entrusted with valuables; Persian women were reputed to be excellent child-minders; Arab girls had a reputation for being accomplished singers; finally, Indian and Armenian women were considered hard to manage, hence unsuited for slavery."

8. B. Lewis 1974: 249, 250-51.

9. B. Lewis 1974: 247. 
there are also some who are rather industrious and useful not only for field service, but also for the various crafts and household management. ${ }^{10}$

Perhaps the fullest example of this type of slave ethnography in the Atlantic context, however, comes from Bryan Edwards's history of the British colonies in the West Indies, written at the close of the 18th century. Edwards develops an extensive classification of the characters of different groups, based in large part on the circumstances in which they lived in Africa. So, for example, the Mandingoes are literate, gentle in disposition, and "exempt from that strong and fetid odour, which exhales from the skin of most of the [more southern natives]"- though they are also more "prone to theft" than other tribes, and "not adapted for hard labour." 11 The Whidah (or Papaws) are "unquestionably the most docile and best-disposed Slaves" imported from Africa; they cheerfully acquiesce in agricultural labour (because of the attention paid to agriculture in their home country), and see any punishment as "the chastisement of legal authority, to which it is their duty to submit patiently"- probably because they are already inured to a state of slavery and a life of labor. ${ }^{12}$ The Eboes are constitutionally timid and prone to melancholy and suicide, though if handled mildly they can become "[reconciled] to their situation" and manifest "as great fidelity, affection, and gratitude, as can reasonably be expected from men in a state of slavery."13

Evidence for a similar discourse in the classical Greek world, by contrast, needs to be patched together from multiple different contexts; no slave-owning manuals on a par to that of Ibn-Butlān survive. ${ }^{14}$ Texts such as Aristotle's Politics or the Hippocratic Airs, Waters, Places, however, consistently identify some peoples as either more obedient, more malleable, or better suited for hard labor than others. (Again, there is frequently a sense that every quality tends to bring with it a downside: that a hardy people tend to be more warlike and less pliant, and so forth.) For Aristotle, Asiatic peoples, because of their warm climate, have skill and intelligence but lack spirit and so have a "predisposition to live slavishly" (Arist. Pol. 1327b24-28). ${ }^{15}$ For the author of Airs, Waters, Places, the climate of the Egyptians and Libyans results in tall men of fine physique but is not conducive to courage, endurance, or spirit (Hippoc. Aer. 12). The inhabitants of the mountainous regions of Europe are likely to be adapted for endurance, but also wild and ferocious (Hippoc. Aer. 24), while those from more hollow regions are more likely to be broad and fleshy than of fine physique, and lacking in endurance

10. Antonil 1922: 91-97 (at 91-92), translated in Conrad 1984: 55-56.

11. Edwards 1793: ii. 62.

12. Edwards 1793: ii. 72-73. Cf. p. 76 on slaves from Congo and Angola, "of a disposition naturally mild and docile. They appear to me to be fitter for domestic service than for field labor. They are said, however, to become expert mechanics; and, what is much to their honour, they are supposed to be more strictly honest than many other of the African tribes."

13. Edwards 1793: ii. 73-4.

14. The difficulties in describing this discourse from fragments are perhaps comparable to those of reconstructing the role of slaves in Greek warfare, or of reconstructing slaves' own ethnic identity, addressed by Hunt 1998, 2015.

15. Cf. Hippoc. Aer. 16, which credits Asiatic feebleness to the uniformity of the seasons (and to monarchy). 
or bravery (though the imposition of nomos might produce such characteristics). For Thracians, according to Herodotus, "not to work is counted most honourable, and to be a worker of the soil is, above all things, dishonourable; to live on war and plunder is the most honourable thing" (Hdt. 5.6). ${ }^{16}$ A waiter in Menander's Aspis condemns

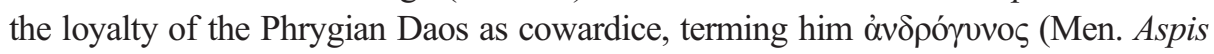

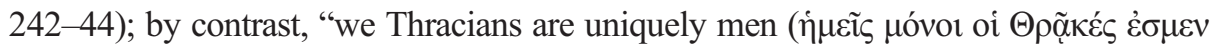
óv $\delta \rho \varepsilon \varsigma)$; - the Getae, by Apollo, yes, real men. That's why we fill the grain-mills

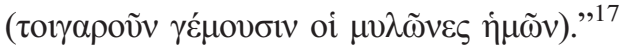

It is tempting to interpret such passages merely as stray stereotypes - in the case of Airs, Waters, Places, the by-product of an abstract environmental determinism. ${ }^{18}$ Such characterisations of foreign people could also, however, be grounded in real-world conditions, specifically in the Greek market in slaves. One source suggests the possibility of fashions in slave origins: just as black pageboys were the rage in 18th-century Europe, so the man of petty ambition (mikrophilotimia) in Theophrastus's Characters insists on having an Ethiopian waiting on him. ${ }^{19}$ However, might perceived ethnic character, rather than just "exotic" background, have been salient also? If slaves from some regions were reputed to be hardier for a particular type of labor, or more pliant, than others - if the Phrygians, for example, were judged to be an ideal slave ethnicity ${ }^{20}$ - this is very likely to have been one factor (alongside others: skills, age, good looks) that dictated a higher price. ${ }^{21}$ (We see something of the interplay between different factors in the scene in which Aesop and other slaves are interrogated in a Samian slave market: Life of Aesop 24-25). As Varro baldly put it in a later context, "in buying human beings as slaves, we pay a higher price for one that is better by nationality" (Varro Ling. 9.93). ${ }^{22}$ If ethnic origin were indeed a factor in the market for slaves, it is likely to have resulted in the intentional confusion or conflation of ethnic groups. If a given people were

16. Cf. Hdt. 2.167 for Thracian (and others') despising of crafts.

17. I.e., have been sent to the mills as punishment: see e.g., Wrenhaven 2012: 51, D. M. Lewis 2018: 41 and 41 n. 49 .

18. For similar concerns on the part of Ibn-Butlān (e.g., that the equitable disposition and lack of courage of the al-Mansuriyya, beyond the river Indus, was the result of the "temperate sun in that region, their temperate food, and their clear water"), see B. Lewis 1974: 246.

19. Theophr. Char. 21.4. Cf. Braund 2011: 126. 18th-century: Patterson 1982: 178 with further references.

20. For Phrygians as emblematic slaves, cf. the famous catalogue of goods at Hermippus fr. $63 \mathrm{KA}$ : "from Euboea pears and fleecy apples, from Phrygia slaves, from Arcadia soldiers for hire."

21. For a list of other such factors (including "exotic origins," citing Theophr. Char. 21.4), D. M. Lewis 2018: 170 n.15; that an "exotic" origin would command a premium is supposed also by Marshall 2013: 182. See Pritchett and Pippin 1956: 278 for a table of slaves by price and ethnicity. Based on a rough comparison between eastern and northern slaves, Pritchett concludes that "differences in price must be attributed to other factors than nationality;" the sample, however, is too small (with other impinging factors unknown) for this to be a reliable conclusion. One Dodona consultant thought to ask the god for advice on pricing: Eidinow 2007: 103.

22. Cf. Braund 2011: 124, suggesting that price was based on skills rather than ethnicity-but, given that ethnicity was bound up with perceived skills and proficiencies, this is a false distinction. For slave pricing, see also Tordoff 2013: 30-31; for differential pricing in the medieval Arabic context, B. Lewis 1992: 13. 
notorious for its unattractive qualities (like the Phasians of Hippoc. Aer. 15: physically gross, yellowish in complexion, and unfitted for labor-as sluggish as the river Phasis itself), it is easy enough to imagine this prompting sharp practice on the part of the traders: ${ }^{23}$ the extension of one ethnic group to encompass its less desirable neighbors, just as fashionable areas of cities typically spread to cover less sought-after addresses.

The characterization of slaves by ethnic origin may then have been further subdivided by gender, in part due to the the differing forms of exploitation. For Bryan Edwards, "the females of this nation [the Eboes] are better laborers than the men, probably from having been more hardly treated in Africa." 24 Stereotypes of Thracians similarly reveal that the characterization of men and women could be sharply divergent: by contrast to indolent Thracian men (Hdt. 5.6), women have a reputation for working the land ( $\mathrm{Pl}$. Leg. 806). Plato's Theaetetus preserves the positive stereotype of the "neat, witty [female] Thracian servant" who mocks the philosopher so busy studying the stars that he falls into a pit (Pl. Tht. 174a). ${ }^{25}$

A regular concern in Arabic manuals is the suitability of the women of any people for sexual exploitation. ${ }^{26}$ So, according to Ibn-Butlān again,

He who wants a slave-girl for pleasure should take a Berber. He who wants a regardful slave-girl who keeps secrets should take a Byzantine. He who wants her for producing offspring should take a Persian. He who wants a wet-nurse should take a zanjiyya. He who wants a singer should take a slave-girl from Mecca. $^{27}$

The women of the Zanj are able to endure hard work and are uncomplaining (so long as their stomachs are filled), but ill-suited for temporary marriage because of their unpleasant smell and the coarseness of their bodies. ${ }^{28}$ Since women's use for sexual exploitation was a priority, traders maximized their profits by disguising any physical blemishes; manuals advised how to identify hidden pregnancies, ${ }^{29}$ and offered the more general wisdom that "one who shops for a thing should not be in dire need of it" (so "a horny buyer should not have a slave-girl displayed to him"30).

23. Braund and Tsetskhladze 1989: 119. For the malleability of ethnic labels attached to slaves, see further below.

24. Edwards 1793: ii. 74.

25. Cf. the Thracian servant girl addressed in familiar terms at Ar. Thesm. 279-95 (with Long 1986: 109),

26. E.g., the 12th-century Al-Samaw'al's Pleasure Park for friends on intimate relations with their beloved: see here esp. Myrne forthcoming, also (for latent pregnancy) Barker 2016: 20-21. For sex slavery, ancient and modern, Patterson 2012: 334; for an attempt to rediscover the reality of the sex slave behind New Comedy, Marshall 2013.

27. Cited by Myrne forthcoming.

28. Cited e.g., by Gordon 1987: 103; cf. Khalidi 1981: 12 for al-Jahiz's positive portrayal of the Zanj, their generosity, rhythmic dancing, their eloquent speaking, and physical stamina. There was also a strong tradition of writing on the virtues of the habash (East African blacks): see e.g., Alawiye 1985 on Ibn al-Jawzī (pp. 35-40, 375-98 for the wider tradition).

29. See here Gordon 1987: 65-66, Barker 2016: 20-21.

30. Myrne forthcoming; cf. B. Lewis 1974: 243-44 (“a lecher should not shop for slave-girls") 
Again Greek sources reveal (slight) traces of similar ideas. The hetairai of Naucratis

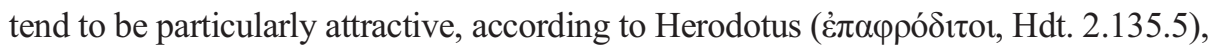
although it is unclear whether this relates to one or more ethnic origin. Scythian slave-

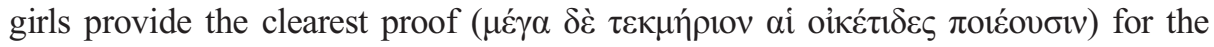
Hippocratic author's thesis that Scythian women are flabby and torpid in physique because of their climate, and that their moistness renders them infertile: now that they are physically active and lean of body, as soon as they go with a man they become pregnant (Hippoc. Aer. 21-22). ${ }^{31}$ And a fragment of the comic playwright Alexis shows prostitutes being prepared for their customers, their numerous shortcomings covered up (fr. 103. 17-18 KA): "she happens to be black?" Plaster her with white lead. "Her skin is too white?" Apply rouge.

Another important incentive for engagement with the ethnic background of slaves was a concern for security. For Bryan Edwards,

[the Koromantyn show a] firmness of body and mind; a ferociousness of disposition; but withal, activity, courage, and a stubbornness, or what an ancient Roman would have deemed an elevation, of soul, which prompts them to enterprizes of difficulty and danger; and enables them to meet death, in its most horrible shape, with fortitude or indifference. They sometimes take to labor with great promptitude and alacrity, and have constitutions well adapted to it. ${ }^{32}$

And yet these very characteristics, because of the Koromantyn's unfamiliarity with enslavement, also make him dangerous. It was Koromantyn slaves (led by an individual named Tacky), who, though they were newly arrived on the island and had received no ill treatment (beyond the fact of their enslavement, we might supply), instigated the rebellion of 1760 , massacred ten white people in their beds, and "literally drank their blood mixed with rum.",33

We can see something of the same mixture of the free-spirited and menacing in the Greek characterization of some northern peoples. The other side of the hardiness that fits the Thracians for physical labor ${ }^{34}$ is their warlike temperament. The Getae are singled out by Herodotus as "the bravest and the most just of all the Thracians"

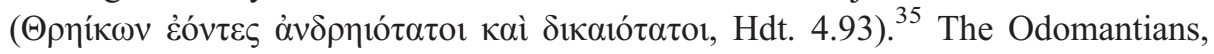
according to a passage of the Acharnians (ventriloquizing ethnographic discourse),

31. For wider concern with the fertility of women, see also Hippoc. Aer. 3-4, 19, Hipp. Nat. mul. 1 (very white women: moister and more subject to fluxes; dark women: drier and more constricted; winecolored women have something of both); cf. Arist. Gen. an. 770a35 for Egypt as an example of a country where women are more prolific. See also Chiasson 2001: $46 \mathrm{n} .32$ for suggestion that the lacuna on Egypt in Hippoc: Aer maybe included a section on Egyptian fertility by contrast to Scythian infertility.

32. Edwards 1793: ii. 63.

33. Edwards 1793: ii. 64-65.

34. Thompson 2003: 146, Wrenhaven 2013: 14. For the Black Sea people of Chalybes as skilled iron-workers, Aesch. PV 714-15, with commentary on Hecataeus BNJ 1 F 202.

35. By contrast to other Thracian tribes such as the Kyrmianai and Nipsaioi, conquered without a struggle by Darius. For the Thracian reputation for cruelty, see Archibald 1998: 100, Tsiafakis 2016: 275-76. 


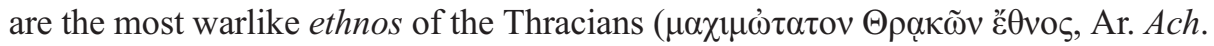
153-57). Classical sources do not preserve warnings against slaves of specific ethnic groups, but Plato and Aristotle reflect the opinion that maintaining a linguistic and ethnic diversity is important both for the safety and the profit of the slave-owner. To enslave those who are $\dot{\alpha} \sigma 0$ $\mu \varphi \omega v o 1$, linguistically distinct from one another, avoids slave revolts, according to Plato's Laws (Pl. Leg. 777d). Aristotle's Politics recommends that the farming population should be made up of slaves, but "not all

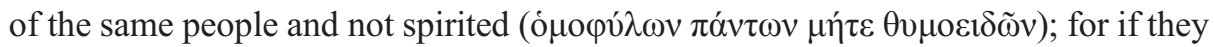
have no spirit, they will be better suited for their work and there will be no danger of

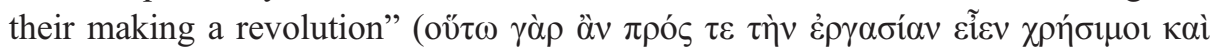

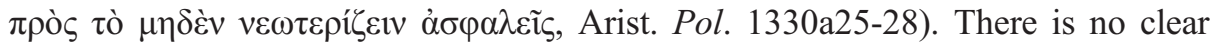
association here of "spirit" with particular ethnicities, but in the context of the characterization of different ethnicities in these terms that we have seen already, and also in light of evidence of the free Greek's fear of being murdered by his slaves, ${ }^{36}$ it seems clear that some amateur ethnographic knowledge would have been considered an essential requirement for the slave-owner. ${ }^{37}$

\section{ETHNOGRAPHY FOUNDED ON SLAVERY?}

So far then, it has been suggested that there was a Greek discourse - primarily an extra-literary one, although it finds its traces in our surviving sources — on the characters of foreign peoples that was rooted in the Greeks' trade in human beings. In making the further suggestion that Greek ethnographic accounts were to a significant extent informed by, and mediated through, the experience of slavery, it is important first to underline the differences between Greek ethnography and the comparative material discussed above. Herodotean ethnography is clearly not overtly focused on the recruitment of suitable slaves, as in the case of Ibn Butlān, or (more obliquely) Bryan Edwards; it does not purport to preserve practical wisdom in any direct sense. ${ }^{38}$ Equally, even if most readers would find it implausible that ethnography motivated by a scientific curiosity would be untainted by political interests, ${ }^{39}$ it is also clear that Greek ethnography was about much more than slavery and the exploitation of foreign peoples. Herodotus and other ethnographic writers took pride in the fineness of their

36. For the expectation of violent animosity from slaves: Pl. Resp. 578e, Antiph. 5.69, Xen. Hier. 4.3, 10.4, Lys. 7.35 .

37. Cf. Rihll 2011: 71 (on Leg. 777d). For fear of slave resistance, Tordoff 2013: 47-48.

38. Ibn-Butlān's Epistle in fact forms part of a wider genre, in which unattributed copying from previous examples was commonplace, and with a heavy reliance on proverbial wisdom, e.g., warning (of the Armenians, B. Lewis 1974: 240-41) that the devil makes work for idle hands: "If you leave a slave for an hour without work, his nature leads him to no good. Only fear and the stick make them behave properly, and their only merit is endurance of toil and heavy labor." See Myrne forthcoming. For a similar Greek discourse on the balance between threats and rewards (e.g., in the Aristotelian Oeconomica) see Tordoff 2013: 48-49; for the extent to which practical or moral lessons are imparted in Herodotus's Histories, see now Harrison 2018.

39. See e.g., Thomas 2000; for a critique, Harrison forthcoming. 
ethnographic distinctions, identifying the multiple subgroups of Thracian or Epirot; ${ }^{40}$ in his account of the Scythians, Timonax is reported to have recorded the existence of as many as 55 Scythian tribes (BNJ $842 \mathrm{~F} 1) .{ }^{41}$ By contrast, the rough-and-ready ethnic identifications of the slave trade are intolerant of fine distinctions, grouping slaves into an abbreviated list of ethnic options (Phrygian, Lydian, Thracian, Colchian and so on ${ }^{42}$ ), and, as with the Atlantic slave trade, naming slaves after their point of embarkation or their place of sale rather than their ultimate origin. ${ }^{43}$ Greek ethnographic writing also embraces a complex theorizing on the relationship between foreign peoples, questioning for example whether similar cultural traits can be traced back to common origins (e.g., Hdt. 2.104-105).

At the same time, however, it is possible to argue that even this more elaborate, more "academic" ethnography may still be grounded in widespread popular conceptions. ${ }^{44}$ Herodotus's elaborate theorizing on the Egyptian origins of the Colchians is predicated on a simplistic set of characteristics: that both have dark skin and curly hair (features, he acknowledges, that are unimportant since other peoples share them also) and that both peoples practice circumcision (Hdt. 2.104-5). Even as Herodotus maps the confusion of ethnicities in Asia Minor, he is careful to relate that the Cappadocians or the Assyrians are the same people termed "Syrians" by the Greeks $(1.72,7.63$; cf. 7.72) - one of the standard ethnics used for slaves. It is possible also that we should envisage the more "academic" ethnography as operating in dialogue with the popular "ethnography" 45 of its audience - whether it reflects, confirms, or subverts popular stereotypes. Just as Herodotus maps the differences and similarities in customs and language of various Thracian and Scythian peoples, relating their land to the rivers that intersect Europe (e.g., Hdt. 4.17-19, 5.3-10), so Bryan Edwards highlights the range of languages spoken ("from Whidah to Angola, the dialects vary at almost every trading river") and the inadequacy of common ethnic terminology, for example that peoples of different languages are improperly grouped together as "Mandingoes."

40. Hdt. 7.110, Theopompus 115 F 215, 223, 382 Xen. An. 7.5.12. See Archibald 1998: 107-12 for the attempt to locate different Thracian tribes geographically.

41. Cf. Thucydides' passing ethnography of the Thracians, 2.96.

42. In one case, a manumission text is explicit on this uncertainty, with a slave "said to be from Heracleia": Fraser 2009: 109. See also the catalogue of slaves in the confiscated property of the metic Cephisodorus, including 5 Thracians (3 women, 2 men), 2 Syrian men, 2 Illyrian men, 3 Carians (1 man 2 children), 1 Lydian woman, 1 Colchian man, and a Maltese: $I G \mathrm{I}^{3} 421$, 11. 33-49. For an example of comparably flexible ethnic classifications of slaves in medieval Arabic sources (al-Samaw'al's use of "Turkish") see Myrne forthcoming. See Hunt 2015: 132 for the reasonable case, citing comparative Brazilian evidence, that such wider ethnic labels may also have been informed by slaves' own interests ("A member of the tribe of the Getae need not feel so alone if he felt he was among fellow Thracians").

43. See Strabo 7.3.12, with Braund and Tsetskhladze 1989, 120, Braund 2011: 124; Varro Ling. 8.21, Pausanias 5.21.10-11. The Koromantyn (or Koromantees) were named from one of the first Gold Coast slave factories, Koromantyn (Edwards 1793: ii. 51; see further Curtin 1969: 185-86) and the Minas from São Jorge da Mina or Elmina, again on the Gold Coast (Conrad 1984: 55-56).

44. On Herodotus's slave-owning assumptions, see the excellent pages of Hunt 1998: 46-52.

45. See Skinner 2012 for the expansion of "ethnography" to embrace wider popular discourse.

46. Edwards 1793: ii. 50-52. 
Such finer subdivisions between ethnic groups may not survive in the slave ethnicities of the marketplace; speculatively, however, we can suggest that they may have been important in the acquisition of slaves. Yvon Garlan has proposed that the settling of scores between neighboring non-Greek communities may have been a significant factor in the Greek slave trade. ${ }^{47}$ This pattern emerges clearly in accounts of the Atlantic slave trade: one early testimony to the Portuguese trade, for example, describes how different groups went out to "hunt each other, as if they were stags" on the arrival of the traders' ships ${ }^{48}$ — a method successful in drawing in many thousands of new slaves. It is possible that, in circumstances again where there was a military and economic imbalance, ${ }^{49}$ and where the demand for cheap labor is likely to have fuelled violence between ethnic groups, something similar would have prevailed in the context of the Greek slave trade. ${ }^{50}$ When Charon of Lampsacus records how the Bithynian tribe of the Bebrykes had, like other peoples, disappeared completely as a result of ongoing war, ${ }^{51}$ there are a range of possibilities: that they had become displaced, their name changed; or that they fell victim to the kind of "slave hunting" which appears to have been an assumed feature of Greek warfare. ${ }^{52}$

More detailed, more "academic" ethnographies then might be interpretedalbeit on a slender evidential basis - as originating from a milieu in which the trade in slaves was central. More substantial evidence for an association between the slave trade and ethnography can perhaps be seen in ethnographic accounts themselves. On two occasions within Herodotus's Histories, Aristagoras of Miletus is portrayed as describing foreign lands in terms of their resources, human and otherwise. ${ }^{53}$ First, in the context of pitching a potential campaign against the Aegean islands to the Persian satrap Artaphernes, he describes the island of Naxos as "not indeed large in size, but fair nevertheless and of fertile soil, as well as near to Ionia, and containing much wealth and many slaves" ( $\mu \varepsilon \gamma \alpha \dot{\alpha} \theta \varepsilon \ddot{i} \mu \varepsilon \grave{v}$ oủ $\mu \varepsilon \gamma \alpha \dot{\alpha} \eta$,

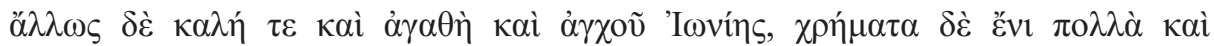
$\grave{\alpha} v \delta \rho \alpha ́ \pi о \delta \alpha, 5.31 .1)$. Likewise, when attempting to entice the Spartan Cleomenes

47. Garlan 1988: 47; see also Rihll 1993: 99 on Hdt. 5.6. There is little explicit evidence for this; though for Greek intervention at local request, see e.g., the invitation of the Doloncians to Miltiades, Hdt. 6.34 .

48. An advisory message to Philip II of Portugal, cited by Conrad 1984: 12. Cf. Perry 2014: 33-37 for a similar mixture of methods (primarily kidnapping and raiding) employed in the medieval trade of slaves from eastern Africa to Egypt and the Middle East.

49. Garlan 1987: 20.

50. See now the important pages of D. M. Lewis 2018: 282-85. Cf. Finley 1962: 59 on the "nonwarfare, non-piracy procedure."

51. BNJ 262 F 7.

52. See e.g., Xen. An. 6.6.38, 7.3.47-8, Hell. 1.2.4-5, Arist. Pol. 1256 b23-26, Men. Aspis 24-49, with Rihll 1993: 83-4. Cf. Braund 2011: 119, 123 for the suggestion that enslavement was an objective of war (contrast Garlan 1987: 10), for the slave trade as driving Greek colonial settlement, and esp. Rihll 1993. Another significant factor in the acquisition of slaves, of course, was trade in other commodities, e.g., the Chian trade to the Black Sea (wine in exchange for slaves): Theopompus FGrHist $115 \mathrm{FF}$ 122a, 276, with Braund 2011: 114-15.

53. Cf. Taylor 2001: 34, strikingly describing "Herodotus's ethnic mapping of Thrace and Scythia" in passing as "in its bare essentials a commodities digest." 
to support the Ionians' revolt against Persian power, Aristagoras does so in terms of the resources on offer: "they who occupy that continent have good things in such quantity as not all the other nations of the world together possess; first gold, then silver and bronze and embroidered garments and beasts of burden and slaves (نં desired" (5.49.4); he then launches into a prospectus of the peoples of Asia. Both passages might be interpreted as referring only to existing slaves: Naxos and the populations of Asia are simply rich in chattel slaves. In the latter case especially, however, it is possible that Aristagoras, in exaggerating the bounty on offer, is being more sweeping and less precise, pointing to the potential for enrichment beyond the "low-hanging fruit" of existing chattel slaves. In the clearest example of this pattern of ideas, the people whose suitability for slavery is assessed are none other than the Greeks themselves. For Herodotus's Scythians, the Ionians, "if they be regarded as free men, . . . [are] the most worthless and cowardly of

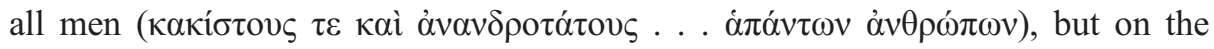
other hand, if regarded as slaves, ... the most attached to their master and the least

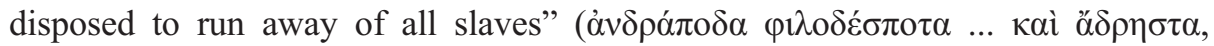
4.142). The passage ironically inverts the usual ethnographic focus on nonGreeks. ${ }^{54}$ Similarly, Aristagoras's characterisation of foreign peoples in terms of their resources may, to an extent, be intended to reflect a distinctly Persian perspective. ${ }^{55}$ And yet, regardless of the particular contexts, the terms in which different populations are characterized are still significant: when the ethnographic gaze turns to a given people, it reveals a (potential) slave population.

\section{JUSTIFYING SLAVERY}

Ethnographic accounts of foreign peoples can also be seen to contain within themselves implicit justifications of those peoples' enslavement. I should be clear: this is not to suggest that there was any general reflection on the justification of, still less a moral anxiety about, slavery, ${ }^{56}$ but that characteristics of a given people are highlighted to suggest (in some cases, it seems, subconsciously) that their enslavement was appropriate, or even beneficial.

Again comparative evidence may be helpful in revealing patterns of ideas in the Greek sources. So, for example, according to the tenth-century al-Maqdisī "It is said that there is no marriage among them [the Bujja], that the child does not

54. Though cf. Skinner 2012, breaking down the distinction between accounts of foreign peoples and Greek poleis.

55. As suggested by Harrison 2015: 27-28, 33. Cf. 4.1-4 (Scythians' slaves) with Hunt 1998: 51-2, 5.13-14 (the story of the Paeonian brothers, Pigres and Mantyas, who cynically stage a demonstration of the industriousness of their sister to impress Darius, with the intended result that the King ordered the transplantation of the Paeonians to Asia), with Archibald 1998: 79-90 for reconstruction of the historical circumstances.

56. Rihll 1993 is a useful corrective; see also the observations of E. Hall 1989a: 219-20. 
know his father, and that they eat people. God knows best." ${ }^{257}$ Similarly, accounts of the Atlantic slave trade focus on the ubiquity of slavery in African societies, on the bloody cruelty of African masters to their slaves, and on reports of cannibalism. ${ }^{58}$ Bryan Edwards cites a Koromantyn slave girl, Clara, as expressing a preference for life in Jamaica on the grounds that "people were not killed there, as in Guiney, at the funeral of their masters;" and he characterizes the "moderate labor" of Jamaican slaves, "unaccompanied with that wretched anxiety to which the poor of England are subject," as "a state of comparative felicity;" "compulsion, to some degree, is humanity and charity." 59

In the classical context, the representation of the Thracians provides the clearest example of a comparable pattern of ideas. ${ }^{60}$ The Thracians are commonly represented as simple-minded and easily led. For Herodotus, the combination of

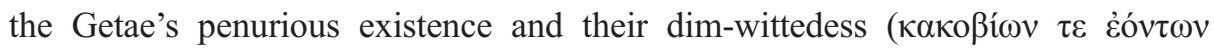

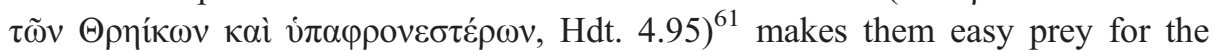
charlatan Salmoxis's false promise of an afterlife in which "they would live for ever and have all good things" (Hdt. 4.95-96). ${ }^{62}$ Polyaenus records the similar story of Cosignas, a priest-leader of two Thracian tribes (the Cebrenii and the Sucaeboae), who impressed his fellow Thracians by joining a number of wooden ladders together and telling them that he could "ascend into heaven to declare to Hera that the Thracians disobeyed him." In response, they begged him "like stupid,

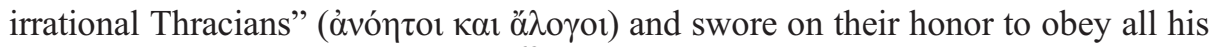
commands (Polyaenus Strat. 7.22). ${ }^{63}$ The Thracians also emerge as morally lax and prone to licentiousness (akolasia), including excessive drinking. ${ }^{64}$ All Thracians,

57. B. Lewis 1974: 110:

58. Edwards 1793: ii. 35-36, 43, 66-67; cf. Conrad 1984: 14 for a contrast in conditions between Guinea and China. For reports of cannibalism as cynically generated to bring enslavement within the law, Conrad 1984: 12.

59. Edwards 1793: ii. 67, 35-36.

60. For Thracian representation in Greek sources and material culture more broadly, see e.g., Archibald 1998: 94-102, Tsiafakis 2000, 2016 (for visual representation of Thracian slaves, pp. 26768), Sears 2013: e.g., 143-49.

61. Cf. Theopompus 115 F 2 (F 39 on Illyrians). Cf. here Rosivach 1999: 148-49, emphasizing philosophical discourse.

62. Cf. the warning of the Persian Megabazus to Darius of the risks of allowing the Greek Histiaeus to establish a base in Thrace, which assumes that the great crowd of Greeks and barbarians will seize upon Histiaeus as their champion $(\pi \rho \circ \tau \tau \dot{\tau} \tau \varepsilon \omega)$ "and do whatever he said both by night and

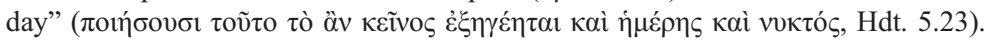

63. This characterization of the Thracians both seems to chime and to be at odds with Herodotus's judgment on their potential strength (5.33): "if ever they should come to be ruled over by one man, or to agree together in one "they would be irresistible and the strongest by far of all nations" (ä $\mu \alpha \chi o ́ v \tau$ '

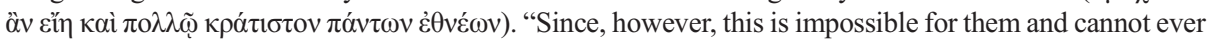

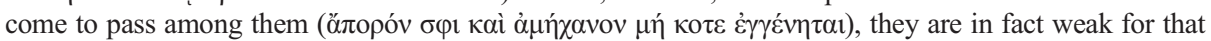
reason." Cf. Thucydides' similar verdict on the Scythians, 2.97.6.

64. Hecataeus BNJ 1 F 34, 169, Theompompus BNJ 115 F 288, Ar. Ach. 141 (cf. 11.153-54 for Thracian bellicosity). Cf. Hecataeus 1 F 154 on beer-drinking Paeonians, Theopompus 115 F 40 for Ardiaeans; for the association of warlike qualities and drunkenness (attributed to Scythians, Celts, Thracians, Carthaginians, Persians, and Iberians), cf. Pl. Leg. 637d-e. 
but especially "we Getae," a character in Menander declares, marry ten or eleven women or more; a man with four or five wives is considered unmarried (Men. fr. 877). But perhaps the proof par excellence of their moral laxity is that, like the Lydians and others, ${ }^{65}$ they allow their daughters to have sex indiscriminately (Hdt. 5.6). Their custom of selling their own children for export then confirms the picture of the devaluation of human life in Thracian society. ${ }^{66}$

A common response to such characterizations is to read them literally. Material distress may indeed have driven Thracians to sell their children into slavery, as in other historical contexts. ${ }^{67}$ And sexual mores may really have differed: "The 'rest of the Thracians,", according to Archibald, "had a much more relaxed attitude to their women and girls, allowing them considerable freedom before marriage."68 Such characterizations, however, are more than merely descriptive-if they are indeed descriptive at all. The trope of female sexual license is one which finds echoes more widely, for example in the Atlantic slave trade. So, for Bryan Edwards, "Negroes" indulge their "mere animal desire . . . as inclination prompts in an almost promiscuous intercourse with the other sex; or at least in temporary connections, which they form without ceremony, and dissolve without reluctance."69 Put together, the whole picture of Thracian society that emerges - of the Thracians as inured to poverty, lacking self-control, collectively mindless, selling their own children, prostituting their daughters - has the effect of justifying their enslavement. As Philostratus later comments of the same custom of selling children attributed to the Phrygians, "they have always been subject to foreign masters, and see nothing disgraceful in slavery."70 The emphasis in Greek characterizations of Thracians on the promiscuity of their women might also serve, more specifically, as an implicit apologia for Thracian women's sexual exploitation in the Greek world. ${ }^{71}$

65. Lydians: Hdt. 1.93-94, Dissoi Logoi 2.16 ("So the Lydians think that it is seemly that girls make money by prostituting themselves and then get married in this way, but among the Greeks no-one would be willing to marry a girl like that"). Macedonians: Dissoi Logoi 2.12 ("The Macedonians think that it is seemly that girls fall in love and have sex with a man before they get married, but unseemly when they are married; but for the Greeks both are unseemly.”) Etruscans: Theopompus 115 F 204.

66. Herodotus 5.6; cf. Xen. An 7.2.38 (Seuthes offers to buy Xenophon's daughter "according to the Thracian custom"); Men. fr. 805, Pollux 7.14 for $\dot{\alpha} \lambda \omega ́ v \eta \tau o \varsigma$ or "salt-bought," Pollux explaining the term by the inhabitants of the Thracian hinterland selling their children for salt, for which Braund and Tsetskhladze 1989: 116. The unrestrained sexual character of non-Greeks is reflected also in their association with masturbation: see here Wrenhaven 2012: 74.

67. So, e.g.,, Finley 1959: 152 (on Hdt. 5.6): slaves “came peacefully, as it were.” For a comparable historical instance (in Upper Egypt) of children being sold as a result of material distress, cf. Perry 2014: 36.

68. Archibald 1998: 175. This seems to chime with a scholarly tendency to see ancient representations of sexual license as pockets of female emancipation (see e.g., Pomeroy 2002 on Sparta).

69. Edwards 1793: ii. 81.

70. Philostratus $V A 8,7.12$.

71. For the sexual abuse of Thracian women slaves specifically: e.g., Ar. Pax 1138-9, Ach. 270-74 with Wrenhaven 2012: 71 (also emphasizing the sexual use of male slaves), D. M. Lewis 2018: 41-42. Clearly, the same point could be generalized to slaves of other origins. The same trope of slave promiscuity might also be reflected in, and justify, constraints on sexual activity among slaves: see Xen. Oec. 9.5 with Johnstone 2011: 78 and 195 n.100. 
The inevitably slavish status of the Thracians is confirmed by physical proof: the Thracian practice of tattooing. Even if there is an acknowledgement-reflected in the characteristic polarities of fifth-century ethnography - that for the Thracians themselves "to be tattooed is considered a mark of good birth" (Hdt. 5.6), in a Greek context tattooes represent a form of degradation. ${ }^{72}$ Indeed, for the author of the Dissoi Logoi, tattooes are a punishment for everyone else apart from the Thracians (Dissoi Logoi 2.13), making the Thracians (on this scale at least) emblematically punishable, emblematically slavish. "It is difficult," as Mireille Lee has observed, "to distinguish punitive tattooing from ethnic markings" in the visual sources; ${ }^{74}$ it is likely, indeed, that there is a leakage between the two in Greek perceptions.

Finally, one further parallel with the evidence from other slave-owning cultures may be the self-cleansing strategy of the expression of sympathy with those enslaved. Bryan Edwards's account of the origins of Caribbean slaves expresses pity for "the miserable people thus condemned to perpetual exile and servitude" and admiration for the extraordinary forebearance even of those executed for their part in the rebellion of $1760:^{75}$

The wretch that was burnt was made to sit on the ground, and his body being chained to an iron stake, the fire was applied to his feet. He uttered not a groan, and saw his legs reduced to ashes with the utmost firmness and composure; after which, one of his arms by some means getting loose, he snatched a brand from the fire that was consuming him, and flung it in the face of his executioner.

In general, expressions of sympathy for slaves in the Greek context focus on the fall from freedom to slavery, and are restricted, for example, to the noble Trojans of Euripides' Hecuba. ${ }^{76}$ But Herodotus's ethnography of Thrace contains one possibly revealing vignette. "When a child is born," he reports of the Trausi, "the kinsmen sit around it and lament all the ills that it must endure from its birth onward, recounting all the sorrows of men" (Hdt. 5.4). Such a sentiment fits into a broader Herodotean and Greek discourse on the instability of human fortune, ${ }^{77}$ but it may also represent some recognition, refracted through the polarities of ethnographic discourse, of the distinctive sufferings of a population earmarked for potential enslavement.

72. Xen. An. 5.4.32, Lys. 13.19, with Jones 1987: 147-48. For Thracian tattoing see Tsiafakis 2015, Lee 2015: 85-6; also Kamen 2010: 98-99.

73. For the association of slavery and punishment, see e.g., the observations of Rosivach 1999: 149-50.

74. Lee 2015: 86 .

75. Edwards 1793: ii. 58-59, 65. Cf. Ibn-Butlān's account of Indian women, cited above.

76. See the nuanced discussion of Hunt 2011: 32-34.

77. Harrison 2000: 60-61. 


\section{IMPLICATIONS}

It remains to draw out the implications of the conclusions reached so far for our understanding of Greek contact with, and representations of, non-Greek peoples.

The first point emerges simply from the scale of slave-owning in the Greek world. This is not the place to recapitulate debates on slave numbers, or the threshold at which a given city "might [display] the mentality of a slave-ridden society.",78 Whether we choose, however, to prefer the lower or higher figures for the slave population of Athens, ${ }^{79}$ it is clear that the large number of slaves was a self-evident fact of Greek life, that slavery was so taken for granted that it could serve as an analogy in countless contexts. ${ }^{80}$ Cities were "bound to contain a large number of slaves, resident aliens and foreigners," according to Aristotle's Politics (Pol. 1326a19). ${ }^{81}$ What was true for Athens appears to have been true of other poleis also: there is reason to suppose that Aegina, Chios, and Corinth had slave populations of a comparable scale. ${ }^{82}$ Overwhelmingly, the majority of Greek contact with foreign peoples was with foreign slaves in their midst. ${ }^{83}$ No matter then how widespread the dissemination of ethnographic literature - and there is evidence in the picking up of Herodotean tropes in Aristophanic comedy that it was indeed widely disseminated ${ }^{84}$ - it seems likely that the popular discourse on the ethnic character of non-Greek slave populations reconstructed above will have dwarfed in its influence (as well as informed) other sources of "knowledge" of barbarian peoples. Each substantial household was a microcosm of the barbarian world, "a mixture of the nationalities of the entire eastern Mediterranean." 85 When free Greeks reached casually for the names of their slaves, whether ethnics (like Syros or Thraitta), stereotypically foreign names (such as Manes - the ancient equivalent of Fritz or Paddy, as David Lewis has put it ${ }^{86}$ ), or other names that referred to ideal characteristics (Pistos, "Trustworthy," Ergophilos,

78. Westermann 1940: 469-70, suggesting that "only a third, even a fourth" of the population of Athens was made up of slaves. For a critical review of the concept of the "slave society," see now D. M. Lewis 2018: 93-104.

79. See e.g., the cautious estimates of Cartledge 1993a: 135, Rihll 2011: 48, Finley 1959: 150; Hansen 1991: 53-54, 90-94 for higher-end figures; Taylor 2001 for a defense of ancient testimonies on slave numbers.

80. See esp. Hunt 2011: 23-25.

81. Cf. Hansen's verdict, 2006: 109, on the numbers of free non-citizens and slaves: "Every polis had plenty of both." See also Tordoff 2013: 18-19 for a nuanced discusson of the presumption of slaveholding within Attic oratory.

82. So e.g., Thuc. 8.40.2 on Chios, with Finley 1959: 115; and the impossible figures for slaves and metics of Ath. 272b-d.

83. Long 1986: 108, E. Hall 1989a: 196; cf. the observation of E. Hall 2006: 202: "It is always a struggle to remind ourselves of the ubiquity of slaves in classical Athens, and what must have been the theatergoer's almost daily experience of dealing with individuals who were both not Greek and almost completely powerless."

84. See e.g., Fornara 1971, Irwin forthcoming, for the problematic Aristophanic evidence (e.g., Ar. Av. 1124-38) for Herodotus's date of publication.

85. Long 1986: 108.

86. D. M. Lewis 2011: 97. 
"Labor-lover"), they were constantly referencing, reaffirming, and reworking a set of shared stereotypes. ${ }^{87}$

If we accept the case that "knowledge" of foreign peoples was to a significant extent mediated through the institution of slavery, this also has significant ramifications for common narratives of Greek views of foreign people. Discussion of the Greek-barbarian polarity frequently focuses on the key trigger for its development: colonization, Athenian imperialism, or, most commonly, the Persian wars. ${ }^{88}$ However, if knowledge of foreign lands and the development of negative stereotypes were generated (directly or indirectly) as a result of a large-scale foreign slave population, were the Persian wars in fact so important as a caesura in the construction of the ideology of the barbarian? And were they so critical to the generation of the idea of the servile nature of barbarians? ${ }^{89}$ As Vincent Rosivach has put it, ${ }^{90}$

if the Athenians were already enslaving barbaroi before the Persian wars. .., it is reasonable to assume that they had also begun to construct an ideological barbaros which depended neither on their experience in the wars nor on the ideology of democracy, but was rather shaped in its earliest stages, more simply, by the Athenians' experience with the enslaved barbaroi in their midst.

Likewise, if the barbarian was already an everyday presence in the Greek world, speculation over whether mainland Greeks "imported" the conception of the barbarian from east Greece is arguably otiose. ${ }^{91}$ Instead we need to envisage an interplay between pre-existing stereotypes of foreign peoples and new sources of "knowledge."

If the institution of slavery was responsible for generating a discourse on the characters of foreign peoples, this might also help to explain why-despite the Greeks' geopolitical weakness vis-à-vis the Persian empire, a fact that they seemed often to acknowledge ${ }^{92}$ - the ideology of Greek cultural superiority was such a prevalent one. $^{93}$ To date, beyond passing mentions of the abstract identification of slaves and foreigners like those with which this article began, it is striking that slavery scarcely

87. For slave names, see esp. now Vlassopoulos 2010; cf. Fragiadakis 1998, Osborne and Byrne 1996. See Tordoff 2013: 24-27 for slave names in comedy, emphasizing discrepancies (as well as parallels) with inscriptional evidence.

88. See e.g., J. Hall 2002, Konstan 2001.

89. As supposed by Garlan 1988: 120.

90. Rosivach 1999: 154; Rosivach puts heavy emphasis on the slaves' inability to speak Greek, leading to their owners' conclusion of their mental incapacity (p. 153). See further below for the suggestion that this language barrier may have been more permeable.

91. Tuplin 1999: 57.

92. For example, through (seemingly proud) local traditions of the influence of their representatives (Artemisia, Histiaeus etc.) in the court of the Persian King.

93. For the wider cultural impact of slavery, see e.g., Rihll 2011: 55-56 (answering Cartledge 1993b), strikingly crediting slavery for the Athenians' "vigorous and robust culture with a 'can-do" mentality," a state of mind that allowed them "to construct great temples in stone, to wage war against numerically superior enemies, to stimulate and manipulate the whole range of human emotions through song and art, and to aspire audaciously to understand the workings of nature." The moral difficulties are better expressed by Finley 1959: 164. 
impinges on accounts of the Greek representation of foreign peoples. ${ }^{94}$ This is especially striking given the scholarly turn that the Greek Barbarian has taken: the increasing emphasis on contact between Greek and Barbarian worlds, and on the fluidity of identities. ${ }^{95}$ When slavery does intrude on modern accounts, moreover, it does so in strikingly neutral, even positive terms - as if all forms of contact equally fostered understanding between cultures. "Imperial warfare and its consequences," according to Kostas Vlassopoulos, "moved people around as exiles, deportees and slaves, and settled them in new and unfamiliar territories." 96 And yet here, in the slave trade, we surely have a form of contact that, rather than working against pejorative representations of foreign peoples, seems overwhelmingly likely to have supported them. At risk of stating the obvious, the institution of slavery was predicated on the effacement of previous identity and underwritten by the fact of widespread violence. ${ }^{97}$ This emerges strikingly from passing vignettes in our sources: Theophrastus's "obnoxious man," for example, standing by while a slave is being beaten (Theophr. Char. 12.12), or the desperate pleas of the slave-boy Lesis, discovered in a letter in the Athenian agora. ${ }^{98}$ This brutal reality drove the generation of an apologetic discourse that served to justify the fact of slavery through ethnographic characterization.

Mention of the testimony of Lesis - a rare slave voice surviving from Greek antiquity ${ }^{99}$ - may remind us finally not to overlook the possibility of slaves' own agency. Beyond popular Greek stereotypes of variously indolent, dependable, hard-working slave populations, might slaves of foreign origins themselves have been a source of (actual) knowledge of foreign lands and peoples? When looking for possible sources for Greek knowledge of foreign people, the tendency in scholarship has been to hypothesize particular individuals or groups as privileged vessels for the transfer of knowledge. According to one long-standing hypothesis, for example, a crucial source for the Persian Empire was Zopyrus, the grandson of the man of the same name who helped the Persian King to take Babylon by stealth, a figure mentioned in passing by Herodotus as having come to Athens (3.160.2). ${ }^{100}$ In an alternative hypothesis, the Athenian sailors caught up in the disaster of Athens' imperial overreach in Egypt in the 450s BC "must have taken back to Greece their share of booty and stories."101 Even if, increasingly, it is appreciated that there was no "iron curtain"102 between Greek and barbarian worlds that needed to be

94. As reflected by indexes: Harrison 2002 refers only to the theory of natural slavery, Malkin 2011 contains no entry for slavery at all.

95. See further Harrison forthcoming.

96. Vlassopoulos 2013: 18.

97. Rihll 2011: 54, commenting on Aeschines 2.156: “Cultivated' manners were thus nurtured in a relationship founded on and underwritten by violence."

98. For text and context, Harris 2004.

99. Beyond Athens, however, Lesis is not a unique slave voice: see e.g., the (no less plaintive) inquiry at Dodona, Dakaris, Vokotopoulou, and Christidis 2013: 1395A: "which god is it best to approach and if I will ever be free."

100. See esp. Wells 1907; cf. the scepticism of (the elder) D. M. Lewis 1985: 105-106 (and on comparable "sources" such as Sataspes, Hdt. 4.45), Miller's 1997: 24 balanced assessment.

101. Miller 1997: 18.

102. The term deployed by D. M. Lewis 1985: 104, in the context of denying its applicability to the Greek context; cf. the observations of Munson 2009: 464-65. 
punctured, the barbarians in the Greeks' midst — metics as well as slaves — are rarely envisaged, and more often dismissed, as a possible source. ${ }^{103}$ Slaves, it has been suggested, were of "such low status as to be untrustworthy," their lack of Greek language a complete bar. ${ }^{104}$ In answer, however, we could point to the role that some slaves serve as privileged intermediaries in Herodotus's Histories: Histiaeus's tattooed slave, or Themistocles's favorite, Sicinnus; ${ }^{105}$ or to the anecdotal mention of influential foreign tutors such as the Thracian Zopyrus, who was given to Alcibiades (Pl. Alc. 122b), ${ }^{106}$ or the trusted nurses of tragedy and of vase-painting; to the stray mentions of how Athenian speech integrated aspects of non-Greek languages; ${ }^{107}$ or to the way in which a former slave's local knowledge is put to use in (the admittedly unusual circumstances of) Xenophon's Anabasis (Xen. An. 4.8.4-7). We could highlight also how writers of later periods deploy slave witnesses: Bryan Edwards at one point cites (for knowledge of conditions in Africa) an "old and faithful Mandingo servant, who stands at my elbow while I write this."108

Peter Hunt has argued compellingly that the evidence for slaves in Athens reveals clear signs of the maintenance of particular slave identities, disclosing for example how slaves presented themselves, in terms of Greek mythical ancestry, as Trojan. ${ }^{109}$ Without falling prey to sentimentalizing relationships between slave and owner, or overlooking the gross disparities in power between them, it remains possible that the wider world described by Herodotus and others-and the Greek world itself-was one that free and slave constructed together. ${ }^{110}$

University of St Andrews
tehh@st-and.ac.uk

103. See, however, Mayor, Colarusso, and Saunders 2014 for the striking, if speculative, hypothesis that nonsense inscriptions on Greek vases in fact reflect the attempt to render fragments of Circassian, Abkhazian and other languages phonetically, and that these may have been relayed through foreign slaves resident in Athens (e.g., p. 487). For non-Greek metics in Athens, see e.g., Xen. Vect. 2.3 (Syrians, Phrygians, and Lydians), Arist. Pol. 1326a19, Theophr. Char. 3.3 with Diggle 2004: 201. For the compelling contention that the majority of Athenian metics were freed slaves, see Akrigg 2015.

104. S. Lewis 1996: 37-38 (and 167 n.38); cf. p. 23 on slaves as "a group disenfranchised from information." The fragmentary evidence (e.g., Pl. Meno 82b, Dem. 19.209, Xen. Cyn. 2.3) suggests linguistic obstacles, but no impermeable barrier. See also Marshall 2013: 182-5 on the possible association of the slave's linguistic isolation and sexual abuse.

105. Tattooed slave: Hdt. 5.35. Sicinnus: Hdt. 8.75 (cf. Plut. Them. 12.3 for his Persian origin).

106. See here Sears 2013: 31, arguing for the possibility of bilingual Thracians employed as interpreters.

107. See esp. the (admittedly jaundiced) observation of [Xen.] Ath. Pol. 2.8, or the claim of knowledge of a Phrygian term at Pl. Cra. 410a. For the caricature of non-Greek speech in Attic comedy, see esp. E. Hall 1989b.

108. Edwards 1793-1801: ii. 61

109. Hunt 2015; see e.g., p. 137 for the case of Atotas the Paphlagonian (IG $\left.\mathrm{II}^{2} 10051\right)$. Hunt's opening example of the Macronian among the Ten Thousand (whose sense of his own background is apparently hazy: Xen. An. 4.8.4-7 with Braund and Tsetskhladze 1989: 120) suggests an element of struggle in maintaining identity.

110. I adapt here the title of Sobel's 1987: 11 study of the shared world view of ante-bellum Virginia, the "deep symbiotic relatedness" of slaves and free. 


\section{BIBLIOGRAPHY}

Akrigg, B. 2015. "Metics in Athens." In C. Taylor and K. Vlassopoulos, eds., Communities and Networks in the Ancient Greek World, 155-73. Oxford.

Alawiye, I. H. 1985. Ibn al-Jawzī's Apologia on Behalf of the Black People and their Status in Islam: a Critical Edition and Translation of Kitāb tanwīr al-ghabash fi fadl 'l-Südān wa'l-Habash. Ph.D. Dissertation. SOAS University of London.

Antonil, A. J. 1922. Cultura e opulência do Brasil por suas drogas e minas. São Paol,

Archibald, Z. H. 1998. The Odrysian Kingdom of Thrace. Orpheus Unveiled. Oxford.

Barker, H. 2016. "Purchasing a Slave in Fourteenth-century Cairo: Ibn al-Akfānī's Book of Observation and Inspection in the Examination of Slaves." Mamlūk Studies Review 19: $1-23$.

Braund, D. 2011. "The Slave Supply in Classical Greece.” In P. Cartledge and K. Bradley, eds., The Cambridge World History of Slavery Vol. 1. The Ancient Mediterranean World, 112-33. Cambridge.

Braund, D. C., and G. R. Tsetskhladze. 1989. "The Export of Slaves from Colchis.” $C Q$ 39.1: 114-25.

Brunschvig, R. 2012. “Abd.” In P. Bearman, T, Bianquis, C. E. Bosworth, E. van Donzel, and W. P. Heinrichs, eds., Encyclopaedia of Islam. 2nd ed. Online.

Cartledge, P. 1993a. The Greeks. A Portrait of Self and Others. Revised. Oxford.

_. 1993b. "'Like a Worm I' the Bud?' A Heterology of Classical Greek Slavery." GaR 40: $163-80$

Chiasson, C. 2001. "Scythian Androgyny and Environmental Determinism in Herodotus

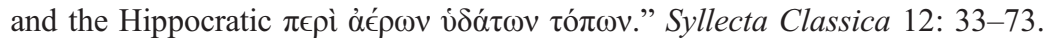

Conrad, R. E. 1984. Children of God's Fire. A Documentary History of Black Slavery in Brazil. Princeton.

Cortese, D., and S. Calderini. 2006. Women and the Fatimids in the World of Islam. Edinburgh.

Curtin, P. D. 1969. The Atlantic Slave Trade: A Census. Madison, Wis.

Dakaris, S., I. Vokotopoulou, and A.F. Christidis. 2013. Ta Chresteria Elasmata Tes Dodones. 2 vols. Athens.

Diggle, J. 2004. Theophrastus Characters. Cambridge.

Edwards, B. 1793. A History, Civil and Commercial, of the British Colonies in the West Indies. 2 vols. 1 st ed. London.

Eidinow, E. 2007. Oracles, Curses and Risk Among the Ancient Greeks. Oxford.

Finley, M. I. 1959. "Was Greek Civilisation Based on Slave Labour?" Historia 8: 145-64. . 1962. "The Black Sea and Danubian Regions and the Slave Trade in Antiquity." Klio 40: 51-59.

Fornara, C. W. 1971. "Evidence for the Date of Herodotus' Publication." JHS 91: 23-34.

Fragiadakis, C. 1988. Die attischen Sklavennamen von der spätarchaischen Epoche bis in die römische Kaiserzeit. Eine historische und soziologische Untersuchung. Athens.

Fraser, P. M. 2009. Greek Ethnic Terminology. Oxford.

Garlan, Y. 1987. "War, Piracy and Slavery in the Greek World." In M. I. Finley, ed., Classical Slavery, 7-21. London.

- 1988. Slavery in Ancient Greece. Revised and expanded ed. Trans. J. Lloyd. Ithaca, N.Y.

Ghersetti, A. 2001. Trattati generale sull'acquisto e l'esame degli schiavi. Catanzaro.

Goitein, S. D. 1993. A Mediterranean Society. The Jewish Communities of the Arab World as portrayed in the Documents of the Cairo Geniza. Vol. 1. Berkeley.

Gordon, M. 1987. Slavery in the Arab World. New Amsterdam. 
Hall, E. 1989a. Inventing the Barbarian. Greek Self-Definition through Tragedy. Oxford. . 1989b. "The Archer Scene in Aristophanes' Thesmophoriazusae." Philologus 133: $38-54$.

- 2006. The Theatrical Cast of Athens. Interactions between Ancient Greek Drama and Society. Oxford.

Hall, J. 2002. Hellenicity. Between Ethnicity and Culture. Chicago.

Hansen, M. H. 1991. The Athenian Democracy in the Age of Demosthenes. Structure, Principles and Ideology. Oxford.

- 2006. Polis. An Introduction to the Ancient Greek City-State. Oxford.

Harquail, C. V. 2010. "Choosing an Au Pair: How Much Does the Home Country Matter?" AuPairMom, April 29, 2010, http://aupairmom.com/choosing-an-au-pair-how-muchdoes-the-home-country-matter/2010/04/29/celiaharquail/

Harris, E. 2004. "Notes on a Lead Letter from the Athenian Agora." HSCP 102: 157-70.

Harrison, T. 2000. Divinity and History. The Religion of Herodotus. Oxford.

- ed. 2002. Greeks and Barbarians. Edinburgh.

- 2015. "Herodotus on the Character of Persian Imperialism (7.5-11)." In A. Fitzpatrick-

McKinley, ed., Assessing Biblical and Classical Sources for the Reconstruction of Persian Influence, History and Culture, 9-48. Wiesbaden.

- 2018. "The Moral of History." In T. Harrison and E. Irwin, eds., Interpreting Herodotus, 335-55. Oxford.

Forthcoming. "Reinventing the Barbarian." $C P$.

Harun, A. S., ed. 1954. Nawādir al-makhțūtāt, ser. 5, n. 15. Cairo.

Hunt, P. 1998. Slaves, Warfare, and Ideology in the Greek Historians. Cambridge.

—. 2011. "Slaves in Ancient Greek Literary Culture." In P. Cartledge and K. Bradley, eds., The Cambridge World History of Slavery vol. 1. The Ancient Mediterranean World, 22-47. Cambridge.

- 2015. "Trojan Slaves in Classical Athens. Ethnic Identity among Athenian Slaves." In C. Taylor and K. Vlassopoulos, eds., Communities and Networks in the Ancient Greek World, 129-54. Oxford.

Irwin, E. Forthcoming. "Dating." In C. Baron, ed., The Herodotus Encyclopaedia. Oxford.

Kamen, D. 2010. "A Corpus of Inscriptions: Representing Slave Marks in Antiquity."MAAR 55: 95-110.

Khalidi, T. 1981. "The Boasts of the Blacks over the Whites." Islamic Quarterly 25: 3-26

Konstan, D. 2001. "To Hellenikon ethnos: Ethnicity and the Construction of Ancient Greek Identity". In E. Gruen, ed. Ancient Perceptions of Greek Ethnicity, 29-50. Cambridge, Mass.

Johnstone, S. 2011. A History of Trust in Ancient Greece. Chicago.

Jones, C. P. 1987. "Stigma: Tattooing and Branding in Graeco-Roman Antiquity." JRS 77: 139-55.

Lauffer, S. 1979. Die Bergswerksklaven von Laureion. 2nd ed. Wiesbaden.

Lee, M. 2015. Body, Dress and Identity in Ancient Greece. Cambridge.

Lewis, B. 1974. Islam from the Prophet Muhammad to the Capture of Constantinople. Vol 2: Religion and Society. New York.

. 1992. Race and Slavery in the Middle East. Revised ed. New York.

Lewis, D. M. 1985. "Persians in Herodotus." In M. H. Jameson, ed., The Greek Historians. Papers Presented to A.E. Raubitschek, 89-115. Palo Alto, Calif.

Lewis, D. M. 2011. "Near Eastern Slaves in Classical Attica and the Slave Trade with Persian Territories." CQ 61: 91-113. 
2018. Greek Slave Systems in their Eastern Mediterranean Context, c. 800-146 BC. Oxford.

Lewis, S. 1996. News and Society in the Greek World. London.

Long, T. 1986. Barbarians in Greek Comedy. Carbondale, Ill.

Malkin, I. 2011. A Small Greek World. Networks in the Ancient Mediterranean. New York.

Marshall, C. W. "Sex Slaves in New Comedy." In B. Akrigg and R. Tordoff, eds., Slaves and Slavery in Ancient Greek Comic Drama, 173-96. Cambridge.

Mayor, A., J. Colarusso, and D. Saunders. 2014. "Making Sense of Nonsense Inscriptions Associated with Amazons and Scythians on Athenian Vases." Hesperia 83: 447-93.

Miller, M. C. 1997. Athens and Persia in the Fifth Century. A Study in Cultural Receptivity. Cambridge.

Müller, H. 1980. Die Kunst des Sklavenkaufs nach arabischen, persischen und türkischen Ratgebern vom 10. bis zum 18. Jahrhundert. Freiburg.

Munson, R. V. 2009. "Who are Herodotus' Persians?" Classical World 102: 457-70.

Myrne, P. Forthcoming. "Purchasing a Slave for Pleasure: From Ibn Buṭlān (d. 1066) to alSamaw'al al-Maghribī (d. 1175)."

Osborne, M. J., and S. G. Byrne. 1996. The Foreign Residents of Athens: An Annex to the Lexicon of Greek Personal Names. Studia Hellenistica 33. Leuven.

Perry, C. 2014. The Daily Life of Slaves and the Global Reach of Slavery in Medieval Egypt, 969-1250 CE. Ph.D. Dissertation. Emory University.

Patterson, O. 1982. Slavery and Social Death. Cambridge, Mass.

—. 2012. "Trafficking, Gender and Slavery: Past and Present." In J. Allain, ed., The Legal Understanding of Slavery. From the Historical to the Contemporary, 322-59. Oxford.

Pomeroy, S. B. 2002. Spartan Women. New York.

Pritchett, W. K., and A. Pippin. 1956. "The Attic Stelai: Part II." Hesperia 25: 178-328.

Rihll, T. E. 1993. "War, Slavery and Settlement in Early Greece." In J. Rich and G. J. Shipley, eds., War and Society in the Greek World, 77-107. London.

2011. "Classical Athens." In P. Cartledge and K. Bradley, eds., The Cambridge World History of Slavery vol. 1. The Ancient Mediterranean World, 48-73. Cambridge.

Robertson, B. 2008. "The Slave Names of $I G \mathrm{i}^{3} 1032$ and the Ideology of Slavery at Athens." In C. Cooper, ed., Epigraphy and the Greek Historian, 79-116. Toronto.

Rosivach, V. 1999. "Enslaving Barbaroi and the Athenian Ideology of Slavery." Historia 48: 129-57.

Sears, M. A. 2013. Athens, Thrace, and the Shaping of Athenian Leadership. Cambridge.

Skinner, J. E. 2012. The Invention of Greek Ethnography. From Homer to Herodotus. New York.

Sobel, M. 1987. The World they Made Together. Black and White Values in EighteenthCentury Virginia. Princeton.

Taylor, T. 2001. "Believing the Ancients: Quantitative and Qualitative Dimensions of Slavery and the Slave Trade in Prehistoric Eurasia." WorldArch 33: 27-43.

Thomas, R. 2000. Herodotus in Context. Ethnography, Science, and the Art of Persuasion. Cambridge.

Thompson, F. H. 2003. The Archaeology of Greek and Roman Slavery. London.

Tordoff, R. 2013. "Introduction: Slaves and Slavery in Ancient Greek Comedy." In B. Akrigg and R. Tordoff, eds., Slaves and Slavery in Ancient Greek Comic Drama, 1-62. Cambridge.

Tsiafakis, D. 2000. "The Allure and Repulsion of Thracians in the Art of Classical Athens." In B. Cohen, ed., Not the Classical Ideal. Athens and the Construction of the Other in Greek Art, 364-89. Leiden. 
2015. "Thracian Tattoos." In D. Boschung, A. Shapiro, and F. Wascheck, eds., Bodies in Transition: Dissolving the Boundaries of Embodied Knowledge, 89-117. Paderborn. 2016. "Ancient Thrace and Thracians through the Athenian Eyes." Thracia 21: 261-82.

Tuplin, C. 1999. "Greek Racism? Observations on the Character and Limits of Greek Ethnic Prejudice.” In G. R. Tsetskhladze, ed., Ancient Greeks West and East, 47-74. Leiden.

Vlassopoulos, K. 2010. "Athenian Slave Names and Athenian Social History.” ZPE 175: 113-44.

2013. Greeks and Barbarians. Cambridge.

Wells, J. 1907. "The Persian Friends of Herodotus." JHS 27: 37-47.

Westermann, W. L. 1940. "Athenaeus and the Slaves of Athens." HSCP Suppl. 1: 451-70.

Wrenhaven, K. 2012. Reconstructing the Slave. The Image of the Slave in Ancient Greece. London.

2013. "Barbarians at the Gate: Foreign Slaves in Greek City-States." Electryone 1: $1-17$. 